\title{
Effect of GeoGebra-Aided REACT Strategy on Understanding of Geometry Concepts
}

\author{
Silfanus Jelatu \\ Ganesha University of Education, Indonesia, \& STKIP Santu Paulus, Indonesia. \\ silfanusjelatu@yahoo.co.id
}

\section{Sariyasa}

Prof. Ganesha University of Education, Indonesia.sariyasa64@yahoo.com

\section{Made Ardana}

Prof., Ganesha University of Education, Indonesia. ardanaimade@undiksha.ac.id

The aim of this research was to examine the effect of GeoGebra-aided REACT strategy on the understanding of geometry concepts and to investigate the interaction between learning strategy and spatial ability on the understanding of geometry concepts. This research involved 60 students of Grade 8 at a private Junior High School in Borong, province of East Nusa Tenggara, Indonesia. The quasi-experimental research with control class without pre-test was done. Prior to the experiment, spatial ability test was conducted to group students into high and low spatial ability. The research data were obtained from a test consisting of five questions to measure students' understanding of geometry concepts. The data were then analyzed using two-way ANOVA. The results of the research show that 1) the GeoGebra-aided REACT strategy leads to a higher achievement of the students on the understanding of geometry concepts if compared to student in conventional groups (expository), and 2) there was no interaction effect between the learning strategy and spatial ability on students' understanding of geometry concepts. The research recommended that GeoGebra-aided REACT strategy can be used in mathematics teaching in Junior High School to improve students' conceptual understanding of geometry concepts.

Keywords: REACT strategy, GeoGebra, conceptual understanding, geometry concept, spatial ability, instructional aids

\section{INTRODUCTION}

In Indonesia's curriculum, geometry is one of the essential materials that taught from elementary school until college. It allows people to understand the world by comparing shapes, objects and their connections (Gunhan, 2014). Geometry is one of the best areas

Citation: Jelatu, S., Sariyasa, \& Ardana, I. M. (2018). Effect of GeoGebra-Aided REACT Strategy on Understanding of Geometry Concepts. International Journal of Instruction, 11(4), 325-336. https://doi.org/10.12973/iji.2018.11421a 
for a child to enter the world of mathematics. The geometrical world can be opened very early because geometrical knowledge correlates very well with children's natural cognition (Swoboda \& Vighi, 2016).

Understanding geometry is essential in itself and for understanding other areas of mathematics. It contributes to logical and deductive reasoning about spatial objects and relationships (Alqahtani \& Powell, 2016). Therefore, the understanding of geometry concepts should be developed effectively in learning mathematics.

Susilawati, Suryadi, \& Dahlan (2017) explain that geometry teaching is expected to provide an attitude or to visualize the relationship and characteristics of geometrical spaces. They emphasize that students should be provided with the opportunity and sufficient supporting learning media so that they can observe, explore, and find out geometrical principles through informal activities before applying what they have informally learned in their formal learning activities.

Sariyasa (2017) describes that traditionally, geometry is taught by pencil and paper which results in difficulties in producing geometrical representation accurately. This may not provide meaningful tools for students in developing their understanding of the geometry concepts. Moreover, in the conventional teaching, geometry is taught textually. The geometry concepts are not related to the real word or students' real life. As proposed by Sanjaya (2008) the traditional teaching strategy is less encouraging to develop the students' thinking skills. The students are directed to memorize the information, so the learning activities become meaningless. Similarly, Agustin (2011) states that the conventional teaching strategy is less able to explore the potentialities and students' understanding. The students have less opportunity to discover and construct mathematical concepts. Thus, the students' difficulty to understand the mathematical concept increases.

The National Council of Teachers of Mathematics (NCTM, 2000) states the importance of using a computer to assist students in learning mathematics, especially geometry. NCTM explains that: "one of the most important challenges in mathematics teaching has to do with the roles of evidence and justification, especially in increasingly technological environments. Using dynamic geometry software, students can quickly generate and explore a range of geometric examples".

Some scholars suggest that the paradigm of learning should be changed, from teachercentered to student-centered, from textual to contextual. Reys et al. (2014) state that students can understand mathematics if they are active in developing their knowledge. Reys et al. (2014) note that mathematical teaching should make sense, the students should be taught to be able to understand the use of mathematics correctly. Teachers may use appropriate manipulative objects to bring math to life and to make the invisible math concepts visible (Golafshani, 2013)

Hutkemri and Zakaria (2012) describe that teaching strategies and techniques are vital in the transfer of new information into the memory in a form that is easily understood. The quality of teaching can be measured by the number of the students who can understand the concepts taught. Successful and effective instruction emphasizes the learning of 
strategies that enable the students to learn with understanding (Jbeili, 2012). Also, the teaching strategy must be accommodated so that all the students learn based on their learning styles (i.e., visual, auditory and kinesthetic). The diversity of the students' learning styles can also affect the students' understanding of the learning materials. In this paper, we introduce REACT strategy aided with GeoGebra as an alternative strategy for teaching geometry.

\section{REACT Strategy and GeoGebra in Teaching Geometry}

REACT (Relating, Experiencing, Applying, Cooperating, and Transferring) strategy is a contextual teaching and learning process (Crawford, 2001) developed by CORD (The Center for Occupational Research and Development) in the United States. These strategies focus on teaching and learning in context-a fundamental principle of constructivism. REACT represents methods used by the best teachers and supported by research on how people learn best (Crawford, 2001). Table 1 shows REACT strategy and descriptions of each step.

Table 1

REACT strategy and descriptions of each step

\begin{tabular}{|c|c|}
\hline & Description \\
\hline Relating & learning in the context of one's life experiences or preexisting knowledge \\
\hline Experiencing & learning by doing, or through exploration, discovery, and invention \\
\hline Applying & learning by putting the concepts to use \\
\hline Cooperating & $\begin{array}{l}\text { learning in the context of sharing, responding, and communicating with other learners } \\
\text { using knowledge in a new context or novel situation-one that has not }\end{array}$ \\
\hline Transferring & been covered in class \\
\hline
\end{tabular}

Reconsideration of the second step of REACT strategy, wide use of GeoGebra software is found relevant for experimentally designed lectures. Crawford (2001) notes that the use of REACT strategy in teaching mathematics at the experiencing stage needs to be collaborated with interactive media in the form of computer software to help the students in the exploration and investigation process. Software such as Geometer's Sketchpad, Cabri, and other dynamic computer software are important to be used to visualize various geometrical objects and abstract concepts.

In this study, we have chosen GeoGebra as a tool of visualization in teaching geometry with REACT strategy. GeoGebra is open source software created by Markus Hohenwarter in 2001. GeoGebra is a dynamic mathematics software combining Geometry, Algebra, and Calculus (Hohenwarter et al., 2008). It is convenient for the students with diverse ability levels, in fact, one of its advantages is its ability to give clear information through figures and graphs which are essential in understanding mathematical concepts (Zulnaidi \& Zamri, 2017).

GeoGebra software is very useful for teachers and students. For teachers, GeoGebra offers an effective opportunity to create interactive learning media that allows students to explore various mathematical concepts. It is also able to help teachers improve students' understanding of mathematical concepts and procedures as this software offers mathematical functions like symbols, graphs and many more (Hutkemri \& Zakaria, 2012; Zulnaidi \& Zamri, 2017). Referring to its name as dynamic mathematics software, this software can be utilized to make the concepts of mathematics dynamic. GeoGebra 
can be used both for solving mathematical problems and for creating virtual learning media or drawing geometrical objects and functional graphs.

GeoGebra facilitates exploration interactively so that it encourages students to involve actively in the learning process (Sariyasa, 2017; Murni et al., 2017). The teaching of mathematics becomes explorative in which the students can see directly and instantly the relationship between the analytic and visual representation of mathematical concepts. A review of literature also shows that using GeoGebra has an impact on students' understanding of geometry. Some studies show that GeoGebra is very effective in teaching mathematics. (Zulnaidi \& Zakaria, 2012; Saha et al., 2010; Zengin et al., 2012; Martín-Caraballo \& Tenorio-Villalón, 2015).

Some studies show that the integration of GeoGebra and REACT strategy is very effective in teaching mathematics. Illhan (2013) used GeoGebra with a modification in the experiencing step of REACT strategy. He finds that students benefit from visual and concrete representations in dealing with GeoGebra. The use of experimentally real activities makes the students understand the topic, grasp the logic of the course and lead them to understand what is taught in the class.

\section{Spatial Ability}

In addition to the choice of appropriate strategies and instructional media, another aspect that needs to be considered in teaching mathematics, in particular, geometry, is spatial ability. Noraini Idris (as cited in Saha et al., 2010) claimed that some factors that caused difficulties in geometrical learning had been identified. They are the language that is used in geometry, visualization ability, and ineffective instruction. Spatial visualization has been linked with geometry learning achievement because geometry is visual. Geometry requires visualization ability, but many students cannot visualize threedimensional objects in a two-dimensional perspective. Without spatial ability, students can't fully appreciate the natural world.

Spatial ability is the ability to see the world accurately and the ability to do some changes with sight and imagination (Armstrong, 2009). The student with spatial ability can recognize, manage and create pictures, shapes, and spaces of three dimensions. Hence, the difference in the level of spatial ability will cause the diversity in mathematical concepts understanding, especially in the spatial material (geometry). Some studies have shown that spatial ability correlates positively with student's mathematical learning achievement (Guay and McDaniel, 1977; Yarmohammadian, 2014).

Spatial ability can be defined as the ability of a person to recognize and perform a description of an object or pattern received by the brain. People with spatial skills will have the capacity to manage two and three-dimensional space. They can recognize shapes, colors, and spaces, and create images in imagination and reality. They are capable of thinking in three dimensions, capable of re-creating the visual world. Students who have good spatial skills are relatively easier to learn by using visual images. Students with spatial ability also have an advantage regarding the imagination of visual forms and can repeat these forms well. The students with spatial skills tend to 
prefer to dabble about the visible objects compared to abstract symbols. They can absorb the learning when presented with the visual objects.

McGee (as cited in Chao \& Liu, 2017) divided spatial abilities into spatial visualization and spatial orientation. Spatial visualization ability is an ability to operate, rotate and turn a solid object with the imagination. Spatial orientation ability is an ability to determine a relative spatial orientation. Meanwhile, Maier (1996) suggests that spatial abilities are skills possessed by people with high-level thinking ability. Maier adds that spatial ability consists of five elements. The five items are spatial perception, visualization, mental rotation, spatial relations, and spatial orientation. (1) Spatial perception is the ability to determine the horizontal and vertical position of an object, (2) Visualization as the ability to visualize objects, (3) Mental rotation is the ability to rotate and turn a solid object with the imagination quickly and precisely, (4) Spatial relations is the ability to understand the configuration of one part with another object and the relationship of one (5) Spatial orientation is intended to orient an object in a given spatial situation.

This study aimed at finding out: (1) whether the understanding of geometry concepts of the students who learn with GeoGebra-aided REACT strategy is higher than those who learn with conventional teaching, (2) whether there is an interaction between GeoGebraaided REACT strategy and spatial ability on students' understanding of geometry concepts.

\section{METHOD}

\section{Model and design}

This research model is quantitative research. The design of this research was a quasiexperiment with control class without pre-test. This design was chosen because this research focused on investigating the effectiveness of GeoGebra-aided REACT strategy to assist students in the understanding of geometry concepts. In this study, we wanted to compare the effectiveness of a new approach to learning strategy with conventional learning strategy. We did not measure improvement in conceptual understanding after treatment.

Before the experiment, a test on spatial ability was administered to know the students' spatial ability. Both students in experiment and control class were divided based on their spatial abilities into high and low groups. The experimental class was taught by using GeoGebra-aided REACT strategy and the control class by using conventional (expository) teaching.

This research used the factorial design with treatment by level design. Fraenkel \& Wallen (2009) described that the factorial design extends the number of relationships that may be examined in an experimental study. They are essentially modifications of either the posttest-only control group or pretest-posttest control group designs, which permit the investigation of additional independent variables. The independent variables in this research were GeoGebra-aided REACT strategy and traditional learning.

Another advantage of a factorial design is that it allows a researcher to study the interaction of an independent variable with one or more other variables, sometimes called moderator variables. The moderator variable can be treatment variable or subject 
characteristic variables (Fraenkel \& Wallen, 2009). In this research, we used the spatial ability as the moderator variable.

The factorial design applied in this research was $2 \times 2$ factorial design as shown in table 2 below.

Table 2

Factorial Design to Study Effects of Learning Strategy and Spatial Ability on Understanding of Geometry Concepts.

\begin{tabular}{llll}
\hline & \multicolumn{2}{c}{ Learning Strategy $(\mathrm{A})$} \\
\hline & & GeoGebra-aided REACT strategy $\left(\mathrm{A}_{1}\right)$ & Conventional $\left(\mathrm{A}_{2}\right)$ \\
\hline Spatial & High $\left(\mathrm{B}_{1}\right)$ & $\mathrm{A}_{1} \mathrm{~B}_{1}$ & $\mathrm{~A}_{2} \mathrm{~B}_{1}$ \\
\cline { 2 - 4 } Ability $(\mathrm{B})$ & Low $\left(\mathrm{B}_{2}\right)$ & $\mathrm{A}_{1} \mathrm{~B}_{2}$ & $\mathrm{~A}_{2} \mathrm{~B}_{2}$ \\
\hline
\end{tabular}

\section{Participants}

There were 60 students of Grade 8 Junior High School at Borong, East Nusa Tenggara, Indonesia involved in this research who were chosen randomly. The students' age between 14 and 15 years old. This sample of 60 students was then grouped into experiment and control group, each of which contains 30 students. Students in both groups were classified into two groups based on the level of spatial ability so that we had 15 students with high spatial ability and 15 students with low spatial ability. This situation can be presented as in table 3 below.

Table 3

The distribution of research participant

\begin{tabular}{llll}
\hline \multicolumn{3}{c}{ Learning Strategy } \\
\hline & & GeoGebra-aided REACT strategy $\left(\mathrm{A}_{1}\right)$ & Conventional $(\mathrm{A} 2)$ \\
\hline Spatial & High $\left(\mathrm{B}_{1}\right)$ & 15 & 15 \\
\cline { 2 - 4 } Ability $(\mathrm{B})$ & Low $\left(\mathrm{B}_{2}\right)$ & 15 & 15 \\
\hline
\end{tabular}

Data Collection

The data in this research were obtained from a test to measure students' understanding of geometry concepts. The test assessed three aspects of understanding, that is, translation, interpretation, and extrapolation. The test was developed by the researchers and was given to both experimental and control group at the end of the study.

Data Analysis

The collected data were then analyzed using two way ANOVA at 5\% level of significance. ANOVA was employed because we wanted to see the main effect and the interaction effect. Before implementing two-way ANOVA, the data were tested for normality and homogeneity. Kolmogorov-Smirnov test was employed to check for normality and homogeneity was tested using Levene's test.

\section{FINDINGS}

Before the experiment, a test on spatial ability was administered to find out the level of students' spatial ability. The test consisted of 20 items with a maximum and minimum score of 20 and zero respectively. In the experiment group, the average score was 11.47 with a maximum and minimum score of 20 and 4 respectively. In the control group, the average score was 11.23 with a maximum and minimum score of 19 and 4 respectively. 
For Based on the test result for spatial ability, students in each group were then classified into two classes, i.e., high and low spatial ability classes.

Two-way ANOVA was conducted to determine the difference in understanding of geometry concepts between the experimental and control groups based on spatial ability. Before the data were analyzed to test the hypothesis, a preliminary test was done to check for normality and homogeneity. The results of this preliminary test were shown in Table 4 and Table 5.

Table 4

Result of Normality Test Using Kolmogorov-Smirnov

\begin{tabular}{lccc}
\hline Group & \multicolumn{3}{c}{ Kolmogorov-Smirnov } \\
\cline { 2 - 4 } & Statistic & df & Sig. \\
\hline Experiment & .136 & 30 & .167 \\
\hline Control & .183 & 30 & .112 \\
\hline
\end{tabular}

The result of Kolmogorov-Smirnov test indicated that the data about students' understanding of geometry concepts have a normal distribution for both groups. In Table 5, we showed the result of Levene's test for homogeneity.

Table 5

The Result of Levene's test for Homogeneity

Dependent Variable: understanding of geometry concepts

\begin{tabular}{cccc}
\hline $\mathrm{F}$ & $\mathrm{df1}$ & $\mathrm{df} 2$ & Sig. \\
\hline 2.012 & 3 & 56 & .123 \\
\hline
\end{tabular}

Table 5 shows that there was no significant variance-covariance difference among dependent variables for all levels of independent variables $(F=2.012, p>0.05)$. This means that the data were homogeneous. As a result, two-way ANOVA was performed to determine if differences exist between the experimental and control groups regarding their conceptual understanding of geometry concept based on spatial ability.

The group means and standard deviations, and the results of the two-way ANOVA are shown in Tables 6 and 7, respectively.

Table 6

Mean and standard deviation of students' score on an understanding of geometry concepts viewed from spatial ability.

\begin{tabular}{lllll}
\hline Group & Spatial Ability & $\mathrm{N}$ & Mean & Std. Dev \\
\hline \multirow{3}{*}{ Experiment } & High & 15 & 80.166 & 12.117 \\
\cline { 2 - 5 } & Low & 15 & 72.5 & 10.69 \\
\cline { 2 - 5 } & Total & 30 & 76.333 & 11.885 \\
\hline \multirow{3}{*}{ Control } & High & 15 & 70.5 & 13.469 \\
\cline { 2 - 5 } & Low & 15 & 52.333 & 7.988 \\
\cline { 2 - 5 } & Total & 30 & 61.416 & 14.273 \\
\hline
\end{tabular}

From Table 6, it can be seen that the average score of students' understanding of geometry concepts in the experiment group is greater than those in the control group. This indicates that GeoGebra-aided REACT strategy has a better effect on students' understanding of geometry concepts than that of conventional teaching. Moreover, 
Table 6 also shows that average score of understanding of geometry concepts for students with the high spatial ability is greater than those with low spatial ability in both experiment dan control groups.

Table 7

Analysis with Two-way ANOVA Dependent Variable: understanding of geometry concepts

\begin{tabular}{llllll}
\hline Source & Type III Sum of Squares & df & Mean Square & F & Sig. \\
\hline Strategy & 3337.604 & 1 & 3337.604 & 26.365 & .000 \\
\hline Spatial & 2502.604 & 1 & 2502.604 & 19.769 & .000 \\
\hline Strategy * spatial & 413.438 & 1 & 413.438 & 3.266 & .076 \\
\hline Error & 7089.167 & 56 & 126.592 & & \\
\hline Total & 297968.750 & 60 & & & \\
\hline
\end{tabular}

Based on the result of hypotheses testing, we can conclude the following.

1. Understanding of geometry concepts of students who are taught with GeoGebraaided REACT strategy is greater than those who are taught with conventional teaching.

2. There is no interaction between GeoGebra-aided REACT strategy and students' spatial ability on an understanding of geometry concepts. This indicates that GeoGebra-aided REACT strategy significantly improves understanding of geometry concepts for students with high and low spatial ability.

\section{DISCUSSION}

The finding concerning the first hypothesis shows that understanding of geometry concepts of the students taught with GeoGebra-aided REACT srategy is better than that of those taught with conventional teaching (expository). The findings of this study are consistent with the study by Saha et al. (2010) and İlhan (2013) which found a positive impact of utilizing mathematical learning software and thus enhancing students learning and understanding. It demonstrates the instructional effectiveness of GeoGebra and REACT strategy compared to the traditional construction tools. Alternative to the teachers to utilize the integrating of learning strategy and mathematics software as a tool in their instructional activities.

GeoGebra-aided REACT strategy through its characteristics and strengths affects the improvement of the students' understanding of geometry concepts if compared to the conventional teaching. The first characteristic was the emphasis on in-depth understanding related to the material taught. The second characteristic was the link with the real world. The teaching strategy started by the teacher by relating the subject matter to be taught with the students' daily life (contextual problem). This means that the lesson emphasizes the relevance of mathematical concepts to be taught to the real context of students' life. At this stage, the ability of students' understanding in making (translation) mathematical models of a problem had been developed.

The third characteristic was that this teaching was done by considering the principles of constructivism. This means that learning environment was designed to make the students able to learn and to some extent enable them to teach themselves through concrete 
experiences. It was reflected in discovery activities by manipulating GeoGebra software, and other exploration activities. Concrete representation helped the students understand the topic, grasp the logic of the course and lead them to understand what was taught in the course (İlhan, 2013). Through the activity of manipulating GeoGebra software, learning becomes more explorative. This media proved to be able to make the students more creative to reason. Also, GeoGebra-aided REACT strategy is associated with an innovative manner to arouse attention. The students focus more emphasis on the learning process. This innovative teaching strategy also reinforces the students' memory. Our results show that all students appreciate in teaching that one is about the experimentally concrete activities, GeoGebra task responds demonstrate a vast range of words including real thoughts about the change on the graph and the focus group interviews show the logic and the visualization of the concepts. When we put all these three results in one word, concrete is the magic word can be seen during the research period. Concrete makes the student understand the topic, grasp the logic of the course and let them know what is taught in the class. İlhan (2013) stated that GeoGebra plays a bridge role between Relating and Experiencing steps to be united to carry out students for the next step of the REACT strategy.

The students were taught to be able to apply the concepts in problems solving in the form of math problems. The students were directed to be active in the learning process so that they could develop their analytical and critical thinking skills, find their concepts, solve the problems and also develop their communication skills. The students were enabled to present the ideas and concepts from all perspectives (interpretation), transferring knowledge to solve unfamiliar problems and make conclusions on the problem (extrapolation).

The fourth characteristic was the application of accommodation of three learning styles, i.e., visual, auditory and kinesthetic. The students' understanding of mathematical concepts will be maximized if the teaching and learning process accommodates the three learning styles.

The finding of the second hypothesis shows that there is no effect of interaction between GeoGebra-aided REACT strategy and the students' spatial ability on students' understanding of geometry concepts. We found that the understanding of geometry concepts of the students who learned with GeoGebra-aided REACT strategy was higher than that of those who learned with conventional (expository) teaching, both for the students with high spatial ability and those with low spatial ability. In other words, the effect of learning strategy and GeoGebra factor on the students' understanding of geometry concept does not depend on the level of students' spatial ability. There is a similar effect of the learning process on mathematical concept understanding of the students in each group of spatial ability. So, the teaching and learning process was relatively suitable for all groups of spatial ability.

This finding is the effect of the use of GeoGebra in teaching. The use of GeoGebra turns out to be able to facilitate an optimal students' learning environment, for both high and low spatial ability students. With the aid from GeoGebra, a geometrical object can be presented dynamically and accurately, so that learning becomes interesting. 
As an example, in the case of investigating the formula for the volume of a pyramid which is obtained from a cube, in the control class, the teacher asked the students to observe a picture of a cube which contained four diagonals cross-cutting at point $\mathrm{T}$, as shown in Figure 1.

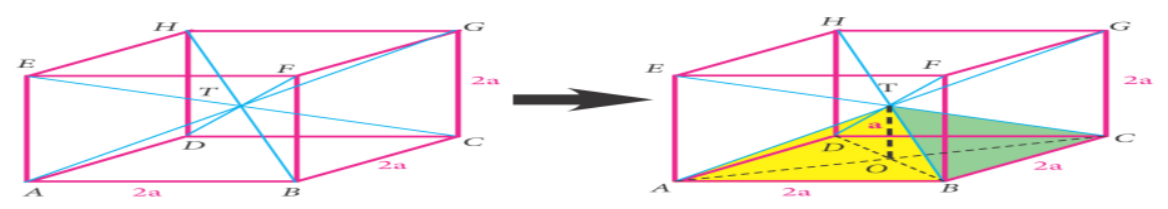

Figure 1

Basic Concept of Pyramid Volume

In this case, the researcher saw that the students with a low spatial ability had difficulty in understanding this picture. They looked confused when asked the meaning and relations between a cube and a pyramid. They were seen confused when asked the meaning and connections between the cube and the pyramid which were formed from the cutting of the diagonals of the space. This was caused by the fact that they did not have the good prior knowledge to construct geometrical objects dynamically in their imaginations. A similar phenomenon did not occur in the group of students with high spatial ability. They seemed to be quick in understanding the representation since they had good prior knowledge in understanding, processing and imagining about a good spatial world both mentally and realistically.

In the experiment class, this case was investigated by manipulating GeoGebra. The visualization process looks like in Figure 2.

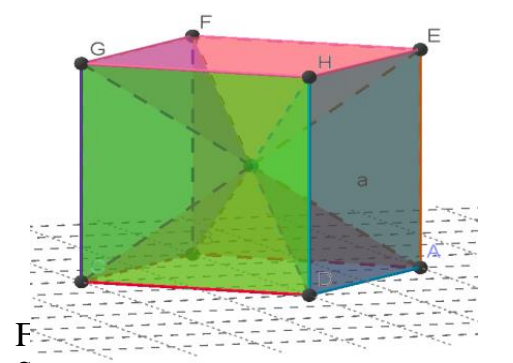

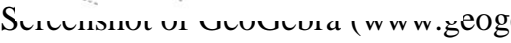

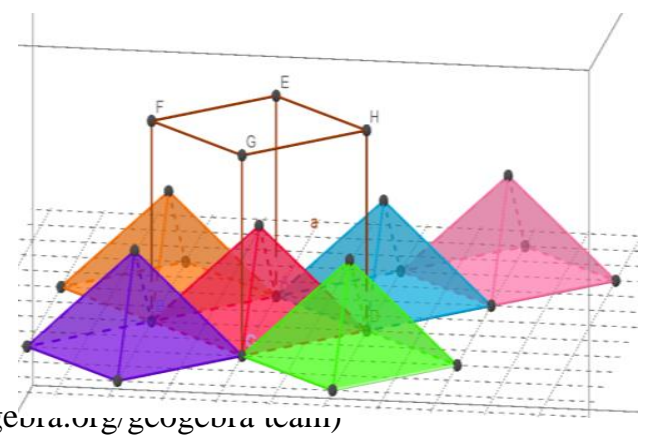

In Figure 2, the formation of six pyramids of quadrangle can be observed by the students directly and dynamically through GeoGebra. The dynamic and accuracy of this GeoGebra have been proven to be capable of mediating the students' understanding. Through GeoGebra, the students with a high spatial ability become more creative in reasoning, while the students with a low spatial ability are made to be more active in understanding various geometrical representations of objects so that understanding can be optimized. GeoGebra has been proven to be capable of optimizing mathematical 
concept understanding of the students with high spatial ability and those with low spatial ability. This finding agrees with the finding of Saha et al. (2010) that GeoGebra can make the students with high spatial ability and those with a low spatial ability balanced in understanding. Their finding also shows that the students with a low spatial ability will get a better understanding if they are taught by using GeoGebra than otherwise.

\section{CONCLUSION AND SUGGESTION}

From the result of the study that had been done, it can be concluded that the students' understanding on geometry concepts will become better if they are taught with GeoGebra-aided REACT strategy than with conventional teaching (expository). Besides, it can also be concluded that there is no significant interaction effect between GeoGebra-aided REACT strategy and spatial ability of the students on the students' understanding of geometry concepts.

Since GeoGebra-aided REACT strategy is effective in improving the students' understanding of geometry concepts, it is then suggested to mathematics teachers to consider the use of GeoGebra-aided REACT strategy in teaching mathematics, especially in teaching geometry.

\section{REFERENCES}

Agustin, M. 2011. Permasalahan belajar dan inovasi pembelajaran. Panduan untuk guru, konselor, psikolog, orang tua dan tenaga kependidikan. Bandung: Refika Aditama.[Agustin, M. 2011. Learning problems and learning innovation. Guidance for teacher, counselor, psychologist, parents, and educators. Bandung: Refika Aditama]

Alqahtani, M.M. \& Powell, A.B. (2016). Instrumental Appropriation of a Collaborative, Dynamic-Geometry Environment and Geometrical Understanding. International Journal of Education in Mathematics, Science and Technology, 4(2), 72-83

Armstrong, T. (2009). Multiple intelligences in the classroom. Virginia: ASCD.

Chao, J. Y., \& Liu, C. H. (2017). A Case Study on the Spatial Conceptualization Abilities for Sixth Grade Elementary Students from Urban, Suburban and Remote Schools. Eurasia Journal of Mathematics, Science and Technology Education, 13(6), 1675-1686.

Crawford, M. L. (2001). Teaching contextually: Research, rationale, and techniques for improving student motivation and achievement in mathematics and science. Texas: CORD.

Fraenkel, J. R. \& Wallen, N. E. (2009). How to Design and Evaluate Research in Education. New York. McGraw-Hill Companies

Golafshani, N. (2013). Teachers' beliefs and teaching mathematics with manipulative. Canadian Journal of Education, 36(3), 137-159

Guay, R. B., \& McDaniel, E. D. (1977). The relationship between mathematics achievement and spatial abilities among elementary school children. Journal for Research in Mathematics Education, 211-215.

Gunhan, B. C. (2014). A case study on the investigation of reasoning skills in geometry. South African Journal of Education, 34(2), 01-19.

Hohenwarter, M., Hohenwarter, J., Kreis, Y., \& Lavicza, Z. (2008). Teaching and calculus with free dynamic mathematics software GeoGebra. Retrieved May 17, 2010. 
Hutkemri \& Zakaria, E. (2012). The effect of GeoGebra on students 'conceptual and procedural knowledge of function. Indian Journal of Science and Technology. 5(12), 10-110

İlhan, E. (2013). Introducing parameters of a linear function at undergraduate level: use of GeoGebra. Mevlana International Journal of Education (MIJE), 3(3), 77-84.

Jbeili, I. (2012). The effect of cooperative learning with metacognitive scaffolding on mathematics conceptual understanding and procedural fluency. International Journal for Research in Education (IJRE). 32, 45-70

Maier, P. H. (1996, March). Spatial geometry and spatial ability-How to make solid geometry solid. In Selected papers from the Annual Conference of Didactics of Mathematics (pp. 63-75).

Martín-Caraballo, A. M., \& Tenorio-Villalón, Á. F. (2015). Teaching Numerical Methods for Non-linear Equations with GeoGebra-Based Activities. Mathematics Education, 10(2), 53-65.

Murni, V., Sariyasa, S., Ardana, I. M. (2017). GeoGebra assists discovery learning model for problem solving ability and attitude toward mathematics. J. of Phys: Conf. Series, 895, 1-6

NCTM (2000). Principles and standards for school mathematics. Reston, VA: National Council of Teachers of Mathematics.

Reys, R. E., Lindquist, M., Lambdin, D. V., \& Smith, N. L. (2014). Helping children learn mathematics. John Wiley \& Sons.

Saha, R. A., Ayub, A. F. M., \& Tarmizi, R. A. (2010). The effects of GeoGebra on mathematics achievement: enlightening coordinate geometry learning. Procedia-Social and Behavioral Sciences, 8, 686-693.

Sanjaya, W. 2008. Strategi Pembelajaran Berorientasi Standar Proses Pendidikan. Jakarta: Kencana Prenada Media Group.[Sanjaya, W. 2008. Learning strategy orienting to process standard of education. Jakarta: Kencana Prenada Media Group]

Sariyasa. (2017). Creating dynamic learning environment to enhance students' engagement in learning geometry. Journal of Physics: Conf. Series, 824 (1), 1-5

Susilawti, W., Suryadi, D., \& Dahlan, J. A. (2017). The Improvement of Mathematical Spatial Visualization Ability of Student through Cognitive Conflict. International Electronic Journal of Mathematics Education, 12(2), 155-166.

Swoboda, E., \& Vighi, P. (2016). Early Geometrical Thinking in the Environment of Patterns, Mosaics, and Isometries. In Early Geometrical Thinking in the Environment of Patterns, Mosaics, and Isometries (pp. 1-50). Springer, Cham.

Zengin, Y., Furkan, H., \& Kutluca, T. (2012). The effect of dynamic mathematics software GeoGebra on student achievement in the teaching of trigonometry. Procedia-Social and Behavioral Sciences, 31, 183-187.

Zulnaidi, H., \& Zakaria, E. (2012). The effect of using GeoGebra on conceptual and procedural knowledge of high school mathematics students. Asian Social Science, 8(11), 102-106.

Zulnaidi, H., \& Zamri, S. N. A. S. (2017). The Effectiveness of the GeoGebra Software: The Intermediary Role of Procedural Knowledge On Students' Conceptual Knowledge and Their Achievement in Mathematics. Eurasia Journal of Mathematics, Science and Technology Education, 13(6), 2155-2180.

Yarmohammadian, A. (2014). The relationship between spatial awareness and mathematic disorders in elementary school students with learning mathematics disorder. Psychology and Behavioral Sciences. 3(1), 33-40. 